\title{
Intersex related gene expression profiles in clams Scrobicularia plana: molecular markers and environmental application
}

Corina M. Ciocan ${ }^{1,4}$, Elena Cubero-Leon ${ }^{2,4}$, William J. Langston ${ }^{3}$, Nick Pope ${ }^{3}$, Keith Cornelius ${ }^{4}$, E.M. Hill ${ }^{4}$, Diana Alvarez-Munoz ${ }^{4}$, Paolo Indiveri ${ }^{4}$, Adelaide Lerebours ${ }^{6}$, Christophe Minier ${ }^{2}$, and Jeanette M. Rotchell ${ }^{5^{*}}$

${ }^{1}$ School of Pharmacy and Biomolecular Sciences, University of Brighton, Lewes Road, Brighton BN2 4GJ, United Kingdom

${ }^{2}$ Laboratoire d'Ecotoxicologie, Universite du Havre, 25 Rue Philippe Lebon, BP540, 766058 Le Havre, France

${ }^{3}$ Marine Biological Association, The Laboratory, Citadel Hill, Plymouth PL1 2PB, United Kingdom

${ }^{4}$ School of Life Sciences, University of Sussex, Falmer, Brighton, BN1 9QJ, United Kingdom ${ }^{5}$ School of Biological, Biomedical \& Environmental Sciences, University of Hull, Cottingham Road, Hull, HU6 7RX, United Kingdom

${ }^{6}$ School of Biological Sciences, Institute of Marine Sciences, University of Portsmouth, Ferry Road, Eastney, Portsmouth PO4 9LY, United Kingdom

*Corresponding author: Jeanette M. Rotchell, e-mail: J.Rotchell@Hull.ac.uk, phone number: +44 (0) 1482 465333, fax number: +44 (0) 1482465458 


\begin{abstract}
Intersex, the appearance of female characteristics in male gonads, has been identified in several aquatic species. It is a widespread phenomenon in populations of the bivalve, Scrobicularia plana, from the southwest coast of the U.K. Genes previously identified as differentially expressed (ferritin, testicular haploid expressed gene, THEG, proliferating cell nuclear antigen, PCNA; receptor activated protein kinase C, RACK; cytochrome B, CYB; and cytochrome c oxidase 1, $C O X 1)$ in intersex clams relative to normal male clams, were selected for characterisation and an environmental survey of the Channel region. Transcripts were significantly differentially expressed at sites with varying intersex incidence and contaminant burdens. Significant correlations between specific gene expressions, key contaminants and sampling locations have been identified, though no single gene was associated with intersex incidence. The results highlight the difficulty in understanding the intersex phenomenon in molluscs where there is still a lack of knowledge on the control of normal reproduction.
\end{abstract}

Keywords: intersex, clams, English Channel, gene expression 


\section{Introduction}

Xenobiotics can interfere with normal gonad development and potentially alter the population structure (Kidd et al., 2007; Lange et al., 2011). Endocrine disrupting chemicals (EDCs), in particular, disrupt the reproductive endocrine system and may cause various biological impacts such as imposex (Strand et al., 2003; Lima et al., 2011), and intersexuality (Kidd et al., 2007; Jobling et al., 2002). Focussing on molluscs, intersex has been reported in several species worldwide including Littoraria angulifera (Costa et al., 2013), Ruditapes sp. (Ponurovsky \& Yakolev 1992; Delgado et al., 2001; Lee et al., 2010), Crassostrea gigas (Lee et al., 2010), Plaxiphora aurata (Scarano \& Ituarte 2009), Mytilus galloprovincialis (Ortiz-Zarragoitia \& Cajaraville 2010) and Scrobicularia plana (Chesman \& Langston 2006; Langston et al., 2007; Gomes et al., 2009; Fossi Tankoua et al., 2012). There is evidence that intersex is a widespread phenomenon in the bivalve, $S$. plana, populations from the south coast of the U.K. (Chesman \& Langston 2006; see also Pope \& Langston, this volume) and France (Fossi Tankoua et al., 2012), and also inducible in an experimental exposure regime using EDCs (Langston et al., 2007). In S. plana intersex is characterised histologically by the occurrence of oocytes among normal testicular tissue (ovotestes) (Langston et al., 2007).

Understanding the cause of the intersex condition in S. plana, and indeed other bivalves, is complicated due to natural sexual differentiation and lack of discreet reproductive organs in such species as follows. Sexual differentiation varies widely among bivalves, from species that are strictly of separate sexes, to those that are almost invariably functionally hermaphroditic. Several mechanisms of sex determination in molluscs are characterised (Vitturi et al., 1998; Guo et al., 1998; Kenchington et al., 2002; Breton et al., 2007; Ghiselli et al., 2012; Breton et al., 2011). Because of these variations in the expression of sexuality, in different species and within different individuals of the same species and at different points in life, the bivalve molluscs represent a challenging group in trying to determine the impact of EDCs. In bivalves, there is also no distinct 
reproductive organ (male or female) and the germinal cells are in direct contact with the surrounding connective tissue (Osada et al., 2007). The developmental stages of sperm and egg follow a similar morphological pattern as seen in vertebrates (Osada et al., 2007). It has been suggested that the initiation of gametogenesis in bivalves depends on several environmental cues, such as temperature, salinity and food availability (Ginsberger-Vogel \& Magniette-Mergault 1981). It is established that vertebrate-like steroids are present in various tissues of molluscs (Zhu et al., 2003; Mouneyrac et al., 2008). A number of enzymatic activities and regulatory pathways in molluscs have also been characterised (Janer \& Porte 2007). Whilst the occurrence of vertebratelike sex steroids is not in doubt, their source and role in molluscs is less clear (Scott 2013). To date, a relatively small number of gonad transcriptomic investigations have been conducted using bivalve molluscs (Ciocan et al., 2011; Boutet et al., 2008; Craft et al., 2010; Banni et al., 2011; LleraHerrera et al., 2013). In these studies, a number of differentially regulated genes in mussel testes, including testis-specific kinases, vitelline lysin and envelope sequences, have been reported (Ciocan et al., 2011). With complications of sexual differentiation and lack of discrete organs, determining the normal reproductive endocrinology and the underlying molecular level cause of induced intersex remain as challenges.

In recent work, gene transcripts involved in cell signalling, cell cycle control, energy production/metabolism, microtubule assembly, and sperm physiology were highlighted as differentially expressed in intersex male clams (Ciocan et al., 2012). Herein, we further characterise a number of the intersex-associated differentially expressed transcripts and determine their expression in natural populations of clam along the U.K. and French coasts of the English Channel, of known EDC contaminant burden, in order to investigate their potential as biological effects markers of EDCs.

\section{Materials and Methods}




\section{Animals}

Scobicularia plana individuals $(\mathrm{n}=30)$ were sampled from more than 100 sites along the Channel coast, between June-July 2009, 2011 and 2012 as part of the DIESE project (see Pope et al, this volume). The sampling sites focussed on in this study were, from west to east, as follows: Avon, Wytch Farm, Parkstone, Totton, St. Denys, Northam, Warsash, Le Havre and Berck respectively (Figure 1). Sites were chosen to represent a range of endocrine disrupting activities (anti-androgenic and estrogenic activities) present in sediments in the Transmanche region (see Alvarez-Muñoz et al; this volume). At the point of sampling, the sex and reproductive status of individual clams was not externally visible. Clams were depurated in 50\% seawater for 2 days (to eliminate sediment), before the gonads were excised. A small sample of gonad from each clam was examined histologically to determine sex and reproductive development stage. Chi-squared tests were performed on sex data to reveal any significant departure from a normal male:female ratio for clams sampled at each location. A piece of gonad (approximately $20 \mathrm{mg}$ ) from each clam was fixed in RNALater (Qiagen Ltd., Crawley, U.K.). A subset of individuals (39.1 $\pm 3.8 \mathrm{~mm}$, SEM, n=9), consisting of mostly normal males with the exception of one normal female at Totton, Warsash and Wytch Farm, were randomly selected from each sampling site for molecular analyses.

\section{Intersex incidence at sampling sites}

The incidence of intersex at each sampling site was determined by histological examination of gonad tissue using criteria as described in Chesman \& Langston (2006).

\section{In vitro measurements of endocrine disrupting activities.}

Sediments were extracted using assisted Accelerated Solvent Extraction and the anti-androgenic activity of extracts was determined as flutamide equivalents using the AR CALUX bioassay as 
detailed in Alvarez-Muñoz et al (2014). The estrogenic activity of extracts was measured as 17ßestradiol equivalents using a yeast recombinant estrogen receptor screen (YES) as described in Peck et al, 2004.

\section{Isolation of candidate genes associated with the intersex condition in male clam gonad tissue}

Candidate genes for development as potential molecular markers of the intersex condition were isolated using the suppressive subtractive hybridisation $(\mathrm{SSH})$ procedure detailed elsewhere (Ciocan et al., 2012). Sequence identities from the forward and reverse libraries were obtained by BLAST searches against the NCBI nucleic acid and protein databases. Sequence reads with $E$-value $<10^{-5}$ were filtered out. Six candidate genes previously identified as up regulated (ferritin, testicular haploid expressed gene (testis antigen 56), THEG) or down regulated (proliferating cell nuclear antigen, PCNA; receptor for activated protein kinase $C, R A C K$; cytochrome $B, C Y B$; cytochrome $c$ oxidase 1, COX1) in intersex clams relative to normal male clams (Ciocan et al., 2012), were selected for characterisation and validation in an environmental survey.

In order to isolate the entire cDNA sequence for each candidate gene, mRNA was purified from individual gonadal total RNA $(1 \mu \mathrm{g})$ using SMART $^{\mathrm{TM}}$ RACE cDNA amplification reagents and protocol (Clontech Laboratories U.K. Ltd., Basingstoke, U.K.). The 3' and 5'ends of the genes were obtained using gene-specific primers (Table 1), designed based on the transcript sequences previously isolated (Ciocan et al., 2012). Amplifications were performed in $50 \mu 1$ reactions using a BioRad iCycler ${ }^{\mathrm{TM}}$ for 5 cycles at $94{ }^{\circ} \mathrm{C}$ for $5 \mathrm{sec}, 72{ }^{\circ} \mathrm{C}$ for $3 \mathrm{~min}, 5$ cycles of $94{ }^{\circ} \mathrm{C}$ for $5 \mathrm{sec}, 70{ }^{\circ} \mathrm{C}$ for $20 \mathrm{sec}$ and $72{ }^{\circ} \mathrm{C}$ for $3 \mathrm{~min}$, followed by 25 cycles at $94{ }^{\circ} \mathrm{C}$ for $5 \mathrm{sec}, 68{ }^{\circ} \mathrm{C}$ for $10 \mathrm{sec}$ and $72{ }^{\circ} \mathrm{C}$ for 3 min. The RACE products obtained were analysed on agarose gels, excised and purified (Qiagen Ltd., Manchester, U.K.). Purified cDNA was ligated into a TA cloning vector (Invitrogen, Paisley, U.K.). Recombinant plasmids were transformed into competent E. coli and selected using 
kanamycin LB plates. Plasmid was purified from transformants for DNA sequence analysis using commercial sequencing (MWG Biotech, Germany) to verify the identity of the product.

\section{Validation of target gene expression in clam gonad samples from sampling sites along the English Channel}

The gene expression of six target mRNAs and three reference mRNAs were analyzed using real time quantitative RT-PCR using clam gonad samples collected as part of the EU Interreg-funded environmental monitoring project DIESE during the seasonal bivalve maturation period (June-July) 2009-2012 (see Pope and Langston, this volume). In brief, total RNA was isolated from individual gonadal tissue using RNeasy reagents (Qiagen, U.K.) and treated with RNA-free DNase I (Qiagen, U.K.) to remove genomic DNA. RNA concentrations were measured with the Quant-iT RNA assay kit (Invitrogen, U.K.) using a Qubit fluorometer (Invitrogen, U.K.). Reverse transcription of $1 \mu \mathrm{g}$ of total RNA samples was carried out using Transcriptor First Strand cDNA synthesis reagents (Roche Applied Science, U.K.). Real-time PCR reactions were performed in duplicate, in a final volume of $25 \mu 1$ containing $12.5 \mu 1$ of qPCR Fast Start SYBR Green Master Rox (Roche Applied Science, U.K.), $5 \mu 1$ of diluted cDNA (1/60) and $3.75 \mu \mathrm{M}$ primers (Table 1). A control lacking cDNA template was included in qPCR analysis to determine the specificity of target cDNA amplification. Amplification was detected with a Mx3005P real time PCR system (Stratagene, U.K.). For each target mRNA, melting curve, gel picture and sequences were analysed in order to verify the specificity of the amplified products and the absence of primer dimers. The amplification efficiency of each primer pair was calculated using a dilution series of cDNA. geNorm software was used to calculate the stability values for reference transcripts $28 S, 18 S$, beta tubulin and actin in the gonadal samples (Vandesompele et al., 2002; Cubero-Leon et al., 2012), Thereafter, the most stable reference gene, $28 S \mathrm{mRNA}$, was used for normalization in the developing and mature gonadal samples. 
All statistical analyses were carried out using SPSS Inc. Chicago, U.S.A. (version 17.0). All data was tested for normality and homogeneity of variances. For normally distributed data, independent t-tests were performed to compare the means. For not normally distributed data nonparametric Mann-Whitney $U$ comparison tests were performed to compare the means. Statistical significance was accepted at $p<0.05$. Possible correlations between levels of target gene expressions (means, 9 sites), anti-androgenic activity (means, 9 sites), estrogenic activity (means, 7 sites), intersex (means, 9 sites) and sex ratio (means, 9 sites) measured at the different sampling sites were investigated using Spearman Rank Correlation. Correlation coefficients $(\rho)$ and significance $\left(\mathrm{H} \neq \mathrm{H}_{0}, \mathrm{H}_{0}\right.$ : the two variables are independents, $\left.\alpha=0.05\right)$ were assessed by the « rcorr » function (Hmisc package) using R 3.0 (R Development Core Team 2013). The association between gene transcriptional responses in gonadal tissue, estrogenicity and anti-androgenicity of sediment extracts, intersex and sex ratio among sites was also assessed by a principal component analysis (PCA), using the "dudi.pca" function (ade4 package).

\section{Results}

\section{Intersex incidence at sampling sites}

Following histological examination, the incidence of intersex and sex ratios were determined and are shown in Table 2. The highest incidence of intersex was observed at Berck (53.3\%), Totton (Southampton)(18.75\%), Warsash (17.65\%), St Denys (15.79\%), Wytch Farm (15.38\%) and Avon (14.28\%). Northam and Le Havre displayed a lower level (5.26\% and 6.67\% respectively) of intersex incidence. No intersex clams were observed at Parkstone sampling site. Only one sampling site, Northam, displayed a skewed sex ratio where more male to female clams were observed (Table 2).

Androgen receptor antagonist (anti-androgen) and estrogen receptor agonist (estrogenic) activities were measured in the extracts of sediments collected from the sampling sites using steroid 
receptor transcription assays. Levels of estrogenic activity ranged from $0.07 \mathrm{ng}$ estradiol equivalents/g dry weight of sediment (ng $E_{2} \mathrm{eq} / \mathrm{g}$ ) for Wytch Farm to 0.8 and $1.3 \mathrm{ng} \mathrm{E}_{2} \mathrm{eq} / \mathrm{g}$ for Parkstone and Northam respectively (Table 2). Anti-androgenic activity in sediments was much higher and ranged between $25 \mu \mathrm{g}$ flutamide equivalents/g ( $\mu \mathrm{g}$ Fluteq/g) for Avon and Wytch farm sites to 66 and $224 \mu \mathrm{g}$ Fluteq/g for St Denys and Northam sites respectively (full data for the Channel regions included in Alvarez-Muñoz et al., this volume).

\section{Isolation of transcripts associated with the intersex condition in male clam gonad tissue}

Six candidate genes were isolated as follows. The open reading frame of $S$. plana ferritin cDNA encodes a polypeptide of 171 amino acids and contains conserved domains of a ferroxidase centre and potential N-glycosylation site (Asn-Gln-Ser) (GenBank Accession Number AFV81451). Blastp analysis indicated that the S. plana ferritin-deduced amino acid sequence shared $80 \%$ identity with the clam, Meretrix meretrix (AAZ20754), 78\% with oyster, Crassostrea gigas (AAP83794), and 75\% with abalone, Haliotis discus hannai (ABH10672) ferritin counterparts.

The open reading frame of a putative $S$. plana THEG-like cDNA encodes a polypeptide of 254 amino acids and contains partially conserved domains of a basic amino acid (PPKR) and ribonucleoprotein consensus motif (GenBank Accession Number AFV81458). Blastp analysis indicated that the putative S. plana THEG-like-deduced amino acid sequence shared $40 \%$ identity with a sea squirt, Ciona intestinalis, (XP_002126454) counterpart.

The S. plana PCNA cDNA encodes a polypeptide of 260 amino acids and contains a conserved, functionally important, connecting loop domain (GenBank Accession Number AFV81453). Blastp analysis indicated that the S. plana PCNA-deduced amino acid sequence shared 77\%, 73\% and 72\% identity with sea hare, Aplysia californica, (XP_00509285), limpet, Lottia gigantea (ESP03901), and human (NP_002583) counterparts respectively. 
The $R A C K$ cDNA isolated from $S$. plana encodes a polypeptide of 318 amino acids and contains a characteristic WD40 domain (GenBank Accession Number AFV81452). Blastp analysis indicated that the $S$. plana RACK-deduced amino acid sequence shared $86 \%, 83 \%$ and $85 \%$ identity with oyster, C. virginica, (CD649264), nile fish, O. niloticus (NP_001266445), and clam, Mya arenaria (CAL48986) counterparts respectively.

The partial $C Y B$ cDNA sequence isolated from $S$. plana encoded 178 amino acids of the protein, including conserved heme $\mathrm{bH}$ and $\mathrm{bL}$ binding sites (17 of the 22 required residues), $\mathrm{Q}_{\mathrm{o}}$ and $\mathrm{Q}_{\mathrm{i}}$ binding sites as well as inter and intra-domain interfaces characteristic of this protein GenBank Accession Number AFV81468). Blastp analysis indicated shared identities of $88 \%, 64 \%$ and $62 \%$ with razor clam, Solecurtus divaricatus (YP_006576439), Manila clam Ruditapes philippinarum (BAB83775), and the gastropod Nucella lamellosa (AAB37287) respectively.

The partial COX1 cDNA isolated from S. plana encoded 389 amino acids of the protein, including a conserved heme-copper binuclear centre and the low-spin heme domain (GenBank Accession Number AFV81464). Blastp analysis indicated shared identities of $79 \%, 70 \%$ and $64 \%$ with the clams $S$, divaricatus (YP_006576433) and Sinonovacula constricta (YP_002038858), and the squid Dosidicus gigas (YP_001425554) respectively.

\section{Quantitative PCR expression of intersex-related genes in clams sampled from the U.K. and}

\section{French coasts.}

Six target mRNAs were selected for qRT-PCR analysis from samples collected at nine English and French sampling locations (Figure 1). Ferritin and THEG had previously been identified as up regulated in S.plana exhibiting intersex condition (Ciocan et al., 2012). Herein, the relative gene expression of ferritin is significantly elevated at four of the sampling locations (Avon, Wytch, St. Denys and Northam) compared with the other sampling sites (Warsash, Le Havre and Berck) (Figure 2). THEG relative gene expression follows a similar trend to ferritin in that, again, 
expression is significantly elevated at Avon, in particular, compared with Parkstone, Totton, and Warsash (Figure 2).

PCNA, RACK, CYB and COXI had previously been identified as down regulated in S. plana exhibiting intersex condition (Ciocan et al., 2012). In this study of different environmental sampling locations, their relative gene expressions also differ significantly (Figure 2). In particular, PCNA gene expression was significantly decreased at Berck relative to all the other sampling sites (Figure 2). RACK gene expression was also significantly decreased at Berck, Le Havre and Parkstone relative to all other sampling sites (Figure 2). $C Y B$ and $C O X 1$ followed a similar trend in that their gene expressions were both significantly decreased at Warsash and Parkstone, in addition to Totton, Berck and Northam for the latter relative to the remaining sampling sites (Figure 2). Of all the sampling sites examined, Berck and Parkstone thus stand out as two locations frequently displaying decreased $P C N A, R A C K, C Y B$ and $C O X 1$ gene expressions relative to the other sampling locations.

Significant Spearman rank correlations were found between levels of selected target gene expressions as follows (Table 3). Ferritin expression is significantly correlated to $R A C K(\rho=0.92$, $p=0.0005), P C N A(\rho=0.82, p=0.007)$ and THEG $(\rho=0.67, p=0.049)$. CYB is significantly correlated to $\operatorname{RACK}(\rho=0.68, p=0.042)$ and $\operatorname{THEG}(\rho=0.73, p=0.025)$. RACK is significantly correlated to THEG $(\rho=0.78, p=0.013)$ and PCNA $(\rho=0.80, p=0.009)$. COX1 expression is negatively correlated to estrogenic sediment activity, although not significantly $(\rho=-0.64, p=$ 0.12) (Table 3). A significant negative correlation was found between anti-androgenic activity and intersex $(\rho=-0.71, p=0.047)$. Estrogenic activity and sex ratio were significantly correlated $(\rho=$ $0.76, p=0.049)$, however this data should be viewed with caution as it was reliant on one site (Northam) which had a significantly different sex ratio to all others (Table 3).

Principal component analysis showed similar patterns of association between gene transcriptional responses, estrogenic and anti-androgenic chemical concentrations, intersex, sex ratio and sampling sites (Figure 3). The expression of $C Y B$ gene is associated to the expression of 
ferritin, THEG and RACK at Wytch Farm (where the expression of these genes are also the highest, Figure 2) (Figure 3). COX1 gene response is associated with the response of ferritin gene (Figure 3, Table 3). PCNA gene response is associated to the Avon sampling site (Figure 3). Intersex is negatively associated to estrogenic activity concentration. In contrast, concentrations of antiandrogenic activity are correlated to sex ratio and estrogenic chemical concentrations at Northam (Figure 3).

\section{Discussion}

In this study, nine sampling locations within the Transmanche region were characterised in terms of selected sediment EDCs contamination levels, incidence rates of intersex, and selected intersexassociated gene expressions in the gonad tissue from the sediment dwelling clam, $S$. plana. The sampling locations were chosen based on previous survey work which revealed that anti-androgenic activity varied in coastal sediments of the Channel region at between $<0.2$ to $224.3 \pm 38.4 \mu \mathrm{g}$ flutamide equivalents/g dry weight of sediment (Alvarez-Muñoz et al., 2014). The anti-androgenic activity of the 9 chosen sites covered the same range of concentrations as the survey and the estrogenic activity measured for 7 of the sites also varied by up to 20 fold allowing for any associations of EDC exposure with gene expression in the clam to be investigated. The sampling sites most heavily impacted by EDCs were St Denys and Northam (Figure 3) (Alvarez-Muñoz et al, this volume). However, the sampling site with the highest incidence of intersex was Berck (53\%), followed by lower, intermediate incidences of $10-20 \%$ at several locations (Table 2). Unfortunately the sediment chemistry analyses were not available for all the sampling sites, including Berck which displayed the highest intersex incidence, yet the partial data available remains in order to facilitate a comparison of the gene expression levels across all sample sites.

Differential relative gene expression for each of the target mRNAs was observed (Figure 2). Ferritin and THEG relative expression were both significantly elevated in male gonads at selected 
sites (Wytch, St. Denys and to a lesser extent Avon and Northam) relative to other sampling sites (Figure 2). In previous work, it was reported that elevated ferritin and THEG gene expression are associated with the intersex condition in clam S. plana (Ciocan et al., 2012). Significantly higher ferritin and THEG gene expression at the Avon and Wytch sites correspond to an intermediate $(\sim 15 \%)$ intersex incidence (Table 3$)$, yet do not however coincide with high estrogenicity and antiandrogenicity sediment levels (Figure 3).

Ferritin is an iron storage protein with a central role in iron metabolism that is conserved in many species, including molluscs (Durrand et al., 2004; Li et al., 2011; Salinas-Clarot et al., 2011). Alterations in ferritin protein expression have previously been reported in the reproductive organs of the hermaphroditic snail, Lymnaea stagnalis, gonad of the red abalone, Haliotis rufescens, and hepatopancreas of Venerupis philippinarium, following exposure to tributyltin/testosterone, thermal stress, and metals/pathogens respectively (Guisti et al., 2013; Salinas-Clarot et al., 2011; Zhang et al., 2013). While ferritin may thus respond to several stressors, this is less likely the case for THEG. THEG encodes for a nuclear protein which is specifically expressed in spermatid cells, though its' role in differentiation of male germ cells has only been characterised for mammalian models to date Mannan et al., 2003; Nayernia et al., 1999). Other than THEG up-regulation in clams exhibiting intersex condition (Ciocan et al., 2012), there are no reports of differential regulation for this gene in any molluscan pollutant-induced 'omics approach studies to date.

Ferritin and THEG also show a positive correlation with $R A C K$ and $C Y B$ relative expressions (Figures $2 \& 3$ ) in this study. Combined, these four gene expressions show a positive correlation with Wytch Farm sampling site, where both sediment EDCs (Figure 3) and intersex incidence (Table 2) values were among the lowest. In contrast to the former genes, $R A C K$ and $C Y B$ were previously identified as down-regulated in S. plana exhibiting intersex condition (Ciocan et al., 2012), and accordingly may represent normal phenotype. In this field application however, while $R A C K$ is down-regulated (Figure 2) at the sampling sites Parkstone and Berck relative to 
other locations, these two sites represent the most variable intersex incidences $(0-53 \%)$ (Table 2). The core of RACK1 is conserved across species, including molluscs (Siah et al., 2007), reflecting its' important role as a shuttle or anchoring protein facilitating the targeting of protein kinase $\mathrm{C}$ proteins (PKCs) to their substrates (Liliental \& Chang, 1998). In mammals, RACK scaffold PKC activation also triggers androgen receptor translocation to the nucleus in the absence of a ligand (Rigas et al., 2003). Herein, increased $R A C K$ expression is correlated, along with increased THEG, $C Y B$ and ferritin, with Wytch Farm sampling site and relatively low sediment EDC and intersex levels (Figures 2 and 3). Down-regulation of $R A C K$ expression in gonadal tissue has been observed at Parkstone, LeHavre and Berck (Figure 2), the areas regarded as either EDC or intersex impacted relative to the other sampling sites (Figure 3 Table 2). Down regulation is also reported in TBTexposed clam, Mya arenaria (Siah et al., 2007), yet up-regulation has been observed in normal mature clam (Siah et al., 2007), gills of oysters, Ostrea edulis, exhibiting disseminated neoplasia (Martin-Gomez et al., 2014) and metal-exposed mussel (Vattoro et al., 2013) perhaps reflecting several roles in cell signalling and proliferation.

CYB is a component of the respiratory chain complex in the mitochondrion and is highly conserved (Howell 1989). In this study, increased $C Y B$ expression is strongly correlated with ferritin and Wytch Farm sampling site (Figure 3), considered a relatively low level of EDC contamination and intersex incidence site, as discussed above. A decrease in $C Y B$ expression has previously been reported in gill and digestive gland tissue from metal-exposed mussels (Varotto et al., 2013; Manelis et al., 1993).

PCNA and COXI relative expressions are elevated at Avon sampling site and to a lesser extent at St Denys/Northam (Figures 2 \& 3). Interestingly, intersex also shows a positive correlation with $P C N A$ and Avon sampling site (Figure 3). Increased PCNA protein expression has previously been detected in histologically normal (Marigomez et al., 1999; Hanselmann et al., 2000; Harris et al., 2006; Franco et al., 2010) and neoplastic (Carella et al., 2013) mollusc tissues. In contrast, 
PCNA down regulation has been reported in gill tissue of mussels experimentally exposed to metals (Varotto et al., 2013). PCNA is an auxiliary protein of DNA polymerases and it's levels increase during G1-S phase of the cell cycle, and is involved in cell proliferation and DNA repair event (Paunesku et al., 2001). In fish, elevated PCNA isoform expressions help drive the spermatogenesis process (Miura et al., 2002). While in mammals, elevated PCNA is also implicated in the suppression of apoptosis (Witko-Sarsat et al., 2010). PCNA can thus be regarded as a general response involved in the control of cell cycle, gamete production and apoptosis pathways, which in the context of normal reproduction perhaps allows generation of gametes at specific seasons (Franco et al., 2010) or in the context of intersex development, perhaps allows gonadal cells to divide inappropriately.

COX1 represents the terminal oxidase in respiratory chains located in the mitochondrial membrane (Poynton et al., 1988) and, again, is conserved across species. Herein increased COX1 expression correlates with the intersex condition and the St Denys/Avon sampling sites (Figure 3). COX1 expression has previously been highlighted as differentially regulated, though subunit specific, in clam exhibiting intersex, mussels exposed to metals, and snail exposed to EDCs (Ciocan et al., 2012; Varotto et al., 2013; Giusti et al., 2013). A study into the mechanistic toxicity of imposex in mud snail, Ilyanassa obsoleta, induced using the antifoulant compound irgarol, similarly reports $C O X 1$ up regulation (Finnegan et al., 2009).

Several of the genes highlighted previously as differentially expressed in intersex clam gonadal tissue (Ciocan et al., 2012), and analysed at sampling sites of differing contaminant burdens herein, could thus be considered as general stress indicators (PCNA, CYB, COX1, ferritin) that may be induced by a variety of pollutant classes generating many endpoints. For instance, elevated PCNA expression has previously been reported in mussels experimentally exposed to the common hydrocarbon contaminant, benzo[a]pyrene, as well as in neoplastic mussel haemocytes (Bollner et al., 2007; Carella et al., 2013). While others, including the down-regulation of THEG 
and $R A C K$ in particular, may provide more specific indicators to the reproductive impairment end point/intersex condition. Yet THEG has failed to appear as differentially expressed in any omicsbased study involving stressor-induced responses using molluscs to date. Furthermore, in this environmental application, none of the gene transcriptions analysed correlated with intersex incidence. This highlights the difficulty in understanding the intersex phenomenon, and others, in molluscs where there is a still a general lack of knowledge in understanding the normal control of reproduction.

In summary, we have isolated and analysed the expression of six genes, previously identified as differentially expressed in gonadal tissue isolated from intersex clam, $S$. plana, in the gonadal tissue of normal individuals sampled at nine locations within the Transmanche region with differing EDC burdens and intersex incidences. Of the sampling locations analysed Wytch Farm is highlighted as having the lower sediment EDC levels and relatively low intersex incidence, while Avon also has lower sediment EDC levels but a higher intersex incidence (Figure 3). Northam, and Parkstone to a lesser extent, are highlighted as the more contaminated sediment EDC burdens, which does not coincide with the higher incidence of intersex (Figure 3). In terms of gene expressions, a number of positive correlations were identified between genes and also sampling sites, yet no single gene expression correlated with intersex incidence alone.

\section{Acknowledgements}

This work was funded by the European Regional Development Fund in the framework of the INTERREG IV A France (Channel) - England programme (DIESE project number 4040). 


\section{References}

Alvarez-Muñoz, D.; Indiveri, P.; Rostkowski, P.; Horwood, J.; Minier, C.; Pope, N.; Langston, W.J.; Hill, E.M. Widespread contamination of coastal sediments in the Transmanche Channel with anti-androgenic compounds. Mar Poll Bull 2014, this volume..

Banni, M.; Negri, A.; Mignone, F.; Boussetta, H.; Viarengo, A.; Dondero, F. Gene expression rhythms in the mussel Mytilus galloprovincialis (Lam.) across an annual cycle. PLoS One 2011, 6, e18904.

Bollner, T.; Prevodnik, A.; Lilja, K. Benzo[a]pyrene up-regulates the expression of the proliferating cell nuclear antigen (PCNA) and multixenobiotic resistance polyglycoprotein (P-gp) in Baltic Sea blue mussels, Mytilus edulis L. Comp. Biochem. Physiol. C, 2007, 145, 265-274.

Boutet, I.; Moraga, D.; Marinovic, L.; Obreque, J.; Chavez-Crooker, P. Characterisation of reproduction-specific genes in a marine bivalve mollusc: Influence of maturation stage and sex on mRNA expression. Gene 2008, 407, 130-138.

Breton, S.; Beaupre, H. D.; Stewart, D. T.; Hoeh, W. R.; Blier, P. U. The unusual system of doubly uniparental inheritance of mtDNA: isn't one enough? Trends Genet. 2007, 23, 465-474.

Breton, S.; Steward, D. T.; Shepardson, S.; Trdan, R. J.; Bogan, A. E.; Chapman, E. G.; Ruminas, A. J.; Piontkivska, H.; Hoeh, W. R. Novel protein genes in animal mtDNA: A new sex determination system in freshwater mussels (Bivalvia: Unionoida)? Mol. Biol. Evol. 2011, 28, 1645-1659. 
Carella, F.; Figueras, A.; Novoa, B.; De Vico G. Cytomorphology and PCNA expression pettern in bivalves Mytilus galloprovincialis and Cerastoderma edule with haemic neoplasia. Dis. Aquat. Org. 2013, 105, 81-87.

Chesman, B. S.; Langston, W. J. Intersex in the clam Scrobicularia plana: a sign of endocrine disruption in estuaries? Biol. Lett. 2006, 2, 420-422.

Ciocan, C. M.; Cubero-Leon, E.; Minier, C.; Rotchell, J. M. Identification of reproduction-specific genes associated with maturation and estrogen exposure in a marine bivalve Mytilus edulis. PLoS One 2011, 6, e22326.

Ciocan, C. M.; Cubero-Leon, E.; Langston, W. J.; Pope, N.; Peck, M. R.; Minier, C.; Rotchell, J. M. 2012. Intersex in Scrobicularia plana: transcriptomic analysis reveals novel genes involved in endocrine disruption. Environ. Sci. Technol. 2012, 46, 12936-12942.

Costa, M. B.; Zamprogno, G. C.; Pedruzzi, F. C.; Dalbem, G. B.; Tognella, M. M. P. Assessing the continuous impact of tributyltin from antifouling paints in a Brazilian mangrove area using intersex in Littoraria angulifera (Lamarck, 1822) as biomarker. Int. J. Oceanogr, 2013, 2013, e769415.

Craft, J. A.; Gilbert, J. A.; Temperton, B.; Dempsey, K. E.; Ashelford, K.; Tiwari, B.; Hutchinson, T. H.; Chipman, K. J. Pyrosequencing of Mytilus galloprovincialis cDNAs: tissue specific expression patterns. PLoS One 2010, 5, e8875. 
Cubero-Leon, E.; Ciocan, C. M.; Minier, C.; Rotchell, J. M. Reference gene selection for qPCR in mussel, Mytilus edulis, during gametogenesis and exogenous estrogen exposure. Env. Sci. Pollut. Res. 2012, 19, 2728-33.

Delgado, M.; Camacho, A. P. Hermaphroditism in Ruditapes decussates (L.) (Bivalvia) from the Galician coast (Spain). Sci. Mar. 2001, 66, 183-185.

Durrand, J-P.; Goudard, F.; Pieri, J.; Escoubas, J-M.; Schreiber, N.; Cadoret, J-P. Crassostrea gigas ferritin: cDNA sequence analysis for two heavy chain subunits and protein purification. Gene 2004, $338,187-195$.

Finnegan, M. C.; Pittman, S.; DeLorenzo, M. E. Lethal and sublethal toxicity of the antifoulant compound Irgarol 1051 to the mud snail Ilyanassa obsoleta. Arch. Environ. Contam. Toxicol. 2009, $56,85-95$.

Franco, A.; Jouaux, A.; Mathieu, M.; Sourdaine, P.; Lelong, C.; Kellner, K.; Berthelin, C.H. Proliferating cell nuclear antigen in gonad and associated storage tissue of the Pacific oyster Crassostrea gigas: seasonal immunodetection and expression in laser microdissected tissues. Cell Tissue Res. 2010, 340, 201-210.

Fossi Tankoua, O.; Amiard-Triquet, C. D. F.; Minier, C.; Mouneyrac, C.; Berthet, B. Physiological status and intersex in the endobenthic bivalve Scrobicularia plana from thirteen estuaries in northwest France. Environ. Poll. 2012, 167, 70-77. 
Ghiselli, F.; Milani, L.; Chang, P. L.; Hedgecock, D.; Davis, J. P.; Nuzhdin, S. V.; Passamonti, M. De novo assembly of the Manila clam Ruditapes philippinarum transcriptome provides new insights into expression bias, mitochondrail doubly uniparental inheritance and sex determination. Mol. Biol. Evol. 2012, 29, 771-786.

Ginsburger-Vogel, T.; Magniette-Mergault, F. The effects of temperature on sexual differentiation in the temperature sensitive thelygenic-intersexual offspring of Orchestia gammarellus (Pallas). 1. Effects of temperature on pubescent females. Int. J. Invert. Reprod. 1981, 4, 39-50.

Giusti, A.; Leprince, P.; Mazzucchelli, G.; Thome, J-P.; Lagadic, L.; Ducrot, V.; Joaquim-Justo, C. Proteomic analysis of the reproductive organs of the hermaphroditic gastropod Lymnaea stagnalis exposed to different endocrine disrupting chemicals. PLoS One 2013, e0081086.

Gomes, T.; Gonzales-Rey, M.; Bebianno, M. J. Incidence of intersex in male clams Scrobicularia plana in the Guadiana Estuary (Portugal). Ecotoxicol. 2009, 18, 1104-1109.

Guo, X.; Hedgecock, D.; Hershberger, W. K.; Cooper, K.; Allen Jr, S. K. Genetic determinants of protandric sex in Pacific oyster, Crassostrea gigas, Evolution 1998, 52, 394-402.

Hanselmann, R.; Smolowitz, R.; Gibson, D. Identification of proliferating cells in hard clams. Biol. Bull. (Woods Hole) 2000, 199, 199-200.

Harris, L.; Lambkin, H.; O’Byrne-Ring, N. Characterisation of cell types in abalone (Haliotis spp.) tissues using immunohistochemical techniques. Aquaculture, 2006, 261, 1413-1421. 
Howell, N. Evolutionary conservation of protein regions in the protonmotive cytochrome $b$ and their possible roles in redox catalysis. J. Mol. Evol. 1989, 29, 157-169.

Janer, G.; Porte, C. Sex steroids and potential mechanisms of non-genomic endocrine disruption in invertebrates. Ecotoxicol. 2007, 16, 145-160.

Jobling, S.; Coey, S.; Whitmore, J. G.; Kime, D. E.; Van Look, K. J. W.; McAllister, B. G.; Beresford, N.; Henshaw, A. C.; Brighty, G.; Tyler, C. R.; Sumpter, J. P. Wild intersex roach (Rutilus rutilus) have reduced fertility. Biol. Reprod. 2002, 67, 515-524.

Kenchington, E.; MacDonald, B.; Cao, L.; Tsagkarakis, D.; Zouros, E. Genetics of motherdependent sex ratio in blue mussels (Mytilus sp.) and implications for doubly uniparental inheritance of mitochondrial DNA. Genetics 2002, 161, 1579-1588.

Kidd, K. A.; Blanchard, P. J.; Mills, K. H.; Palace, V. P.; Evans, R. E.; Lazorchak, J. M.; Flick, P. W. Collapse of a fish population after exposure to a synthetic estrogen. Proc. Natl Acad. Sci. USA 2007, 104, 8897-8901.

Lange, A.; Paull, G. C.; Hamilton, P. B.; Iguchi, T.; Tyler, C. R. Implications of persistent exposure to treated wastewater effluent for breeding in wild roach (Rutilus rutilus) populations. Environ. Sci. Technol. 2011, 45, 1673-1679.

Langston, W. J.; Burt, G. R.; Chesman, B. S. Feminisation of male clams Scrobicularia plana from estuaries in Southwest UK and its induction by endocrine disrupting chemicals. Mar. Ecol. Prog. Ser. 2007, 333, 173-184. 
Li, C.; Li, H.; Su, X.; Li, T. Identification and characterization of a clam ferritin from Sinonovacula constricta. Fish Shellfish Immunol. 2011, 30, 1147-1151.

Liliental, J.; Change, D. D. RACK-1, a receptor for activated protein kinase C, interacts with integrin b subunit. J. Biol. Chem. 1998, 273, 2379-2383.

Lima, D.; Reis-Henriques, M. A.; Silva, R.; Santos, A. I.; Castro, F. C.; Santos, M. M. Tributyltininduced imposex in marine gastropods involves tissue-specific modulation of the retinoid $\mathrm{X}$ receptor. Aquat. Toxicol. 2011, 101, 221-227.

Lee, J. S.; Lee, Y. G.; Kang, S. W.; Park, J. S.; Lee, D. G.; Jeon, M. A.; Ju, S. M. Intersexuality of Crassostrea gigas and Ruditapes phillipinarum in Southern coastal waters of Korea. Environ. Health Toxicol. 2010, 25, 287-294.

Llera-Herrera, R.; Garcia Gasca, A.; Abreu Goodger, C.; Huvet, A.; Ibarra, A.M. Identification of male gametogenesis expressed genes from the scallop Nodipesten subnodosus by suppressive subtraction hybridization and pyrosequencing. PLoS One 2013, 8, e73176

Manelis, R.; Hornung, H.; Fishelson, L.; Yawetz, A. The effects of exposure to heavy metal ions cytochrome B5 and components of the mixed function oxidases from the digestive gland microsomes of the mollusc Monodonta turbinata. Water Sci. Technol. 1993, 27, 473-480. 
Mannan, A. U.; Nayernia, K.; Mueller, C.; Burfeind, P.; Adham, I. M.; Engel, W. Male mice lacking the Theg (testicular haploid expressed gene) protein undergo normal spermatogenesis and are fertile. Biol. Reprod. 2003, 69, 788-796.

Marigomez, I.; Lekube, X.; Cancio, I. Immunochemical localisation of profilerating cells in mussel digestive gland tissue. Histochem. J. 1999, 31, 781-788.

Martin-Gomez, L.; Villalba, A.; Caraballal, M. J.; Abollo, E. Cloning and charcterisation of neoplasia-related genes in flat oyster Ostrea edulis. Infection Genet. Evol. 2014, 23, 138-149.

Miura, C.; Miura, T.; Yamashita, M. PCNA protein expression during spermatogenesis of the Japanese eel (Anguilla japonica). Zool. Sci. 2002, 19, 87-91.

Mouneyrac, C.; Linot, S.; Amiard, J.-C.; Amiard-Triquet, C.; Metais ,I; Durou, C.; Minier, C.; Pellerin, J. Biological indices, energy reserves, steroid hormones and sexual maturity in the infaunal bivalve Scrobicularia plana from three sites differing by their level of contamination. Gen. Comp. Endrocrinol. 2008, 157, 133-141.

Nayernia, K.; von Mering, M. H. P.; Kraszucka, K.; Burfeind, P.; Wehrend, A.; Kohler, M.; Schmid, M.; Engel, W. 1999. A novel testicular haploid gene (THEG) involved in mouse spermatid-Sertoli cell interaction. Biol. Reprod. 1999, 60, 1488-1495.

Ortiz-Zarragoitia, M.; Cajaraville, M. P. Intersex and oocyte atresia in a mussel population from the Biosphere's Reserve of Urdaibai (Bay of Biscay). Ecotox. Environ. Safety 2010, 73, 693-701. 
Osada, M.; Nakamara, S.; Kijima, A. Quantitative analysis of pattern of gonial proliferation during sexual maturation in Japanese scallop Patinopecten yessoensis. Fisheries Sci. 2007, 73, 1318-1324.

Peck, M.; Gibson, R. W.; Kortenkamp, A.; Hill, E. M. Sediments are major sinks of steroidal estrogens in two United Kingdom rivers. Environ. Toxicol. Chem. 2004, 23, 945-952.

Pope, N. D.; Childs, K.; Dang, C.; Davey, M. S.; O’Hara, S. C. M.; Langston, C.; Minier, C.; Pascoe, P. L.; Shortridge E.; Langston, W. J. (this volume). Intersex in the clam Scrobicularia plana (Da Costa): Widespread occurrence in English Channel estuaries and surrounding areas. Mar. Pollut. Bull.*

Paunesku, T.; Mittal, S.; Proti, M.; Oryhon, J.; Korolev, S.V.; Joachimiak, A.; Woloschak, G.E. Proliferating cell nuclear antigen: ringmaster of the genome. Int. J. Radiat. Biol. 2001, 77, $1007-$ 1021.

Ponurovsky, S. K.; Yakolev, Y. M. The reproductive biology of the Japanese littleneck, Tapes phillippinarumi (Bivalvia; Veneridae). J. Shell. Res. 1992, 11, 265-277.

Poynton, R. O.; Trueblood, C. E.; Wright, R. M.; Farrell, L. E. Expression and function of cytochrome c oxidase subunit isologues. Ann. New York Acad. Sci. 1988, 550, 289-307.

Rigas, A. C.; Ozanne, D. M.; Neal, D. E.; Robson, C. N. The scaffolding protein RACK1 interacts with androgen receptor and promotes cross talk through a protein kinase C signalling pathway. $J$. Biol. Chem. 2003, 278, 46087-46093. 
Salinas-Clarot, K.; Gutierrez, A. P.; Nunez-Acuna, G.; Gallardo-Escarate, C. Molecular characterization and gene expression of ferritin in red abalone (Haliotis rufescens). Fish Shellfish Immunol. 2011, 30, 430-433.

Scarano, A.; Ituarte, C. First report of a case of occasional hermaphroditism in Polyplacophora. $J$. Mollus. Stud. 2009, 75, 91-92.

Scott, A. P. Do molluscs use vertebrate sex steroids as reproductive hormones? II Critical review of the evidence that steroids have biological effects. Steroids 2013, 78, 268-281.

Siah, A.; Masson, R.; Loup, B.; Bultelle, F.; Pellerin, J.; Leboulanger, F.; Danger, J. M. Receptor activated protein kinase is down-regulated in the male gonad of the marine bivalve mollusc Mya arenaria exposed to tributyltin. Aquat. Toxicol. 2007, 83, 295-305.

Strand, J.; Asmund, G. Tributyltin accumulation and effects in marine molluscs from West Greenland. Environ. Pollut. 2003, 123, 31-37.

Vandesompele, J.; De Preter, K.; Pattyn, F.; Poppe, B.; Van Roy, N.; De Paepe, A.; Speleman, F. Accurate normalization of real-time quantitative RT-PCR data by geometric averaging of multiple internal control genes. Genome Biol. Res. 2002, 3, 0034.1-0034.11.

Varotto, L.; Domeneneghetti, S.; Rosani, U.; Manfrin, C.; Cajaraville, M. P.; Raccanelli, S.; Pallavicini, A.; Venier, P. DNA damage and transcriptional changes in the gills of Mytilus galloprovincialis exposed to nanomolar doses of combined metal salts. PLoS One, 2013, e54602. 
Vitturi, R.; Colomba, M. S.; Caputo, V.; Pandolfo, A. XY chromosome sex systems in the neogastropods Fasciolaria lignaria and Pisania striata. J. Heredity 1998, 89, 538-543.

Witko-Sarsat, V.; Mocek, J.; Bouayad, D.; Tamassia, N.; Ribeil, J. A.; Candahl, C.; Davezac, N.; Reuter, N.; Mouthon, L.; Hermine, O.; Pederzoli-Ribeil, M.; Cassatella, M. A. Proliferating cell nuclear antigen acts as a cytoplasmic platform controlling human neutrophil survival. J. Exp. Med. 2010, 207, 2631-2645.

Zhang, L.B.; Sun, W.; Cai, W.; Zhang, Z.; Gu, Y. G.; Chen, H. G.; Ma, S. W.; Jia, X. P. Differential response of two ferritin subunit genes from Venerupis philippinarum following pathogen and heavy metals challenge. Fish Shellfish. Res. 2013, 35, 1658-62.

Zhu, W.; Mantione, K.; Jones, D.; Salamon, E.; Cho, J. J. The presence of 17-beta estradiol in Mytilus edulis gonadal tissues: evidence for estradiol isoforms. Neuroendocrinol. Lett. 2003, 24, $137-140$. 


\section{Figure and Table Legends}

Figure 1. Map showing the sampling stations (Map data (C) 2014 Google). 1: Avon; 2: Wytch Farm; 3: Parkstone; 4: Totton; 5: St Denys; 6: Northam; 7: Warsash; 8: Le Havre; 9: Berck.

Figure 2. Relative gene expression of target genes sampled from nine geographical sampling sites (y axis in logarithmic scale in base 10). Data are plotted as mean \pm SEM ( $n=9)$. Numbers (see numbering legend on the graph) denote significant differences between stations $(\mathrm{p}<0.05)$ and numbers in bold denote highly significant differences between stations $(\mathrm{p}<0.01)$.

Figure 3. Principal component analysis showing the association between gene transcriptional responses, concentrations of estrogenic and androgenic chemicals, intersex, sex ratio and sites. Axis 1 represents $44 \%$ of variance. Axis 2 represents $29 \%$ of variance.

Table 1. Primers designed for RACE and real-time PCR and expected amplicon size (bp).

Table 2. Incidence of intersex, sex ratios and sediment concentrations of endocrine disrupting activity at sampling sites. *Significantly different from unity, Chi squared test. $\mathrm{n}=30$ for intersex incidence and sex ratio at each sampling site. $n=3$ analytical determinations for endocrine disrupting activity. nd-not determined.

Table 3. Matrix showing the Spearman rank correlation coefficients $(\rho)$ and levels of significance ( $p$ ) between target gene expressions (means, 9 sites), anti-androgenic activity (means, 8 sites), estrogenic activity (means, 7 sites), intersex (means, 9 sites) and sex ratio (means, 9 sites) measured at the different sampling sites. Significant values $(p<0.05)$ are shaded. 
Figure 1.

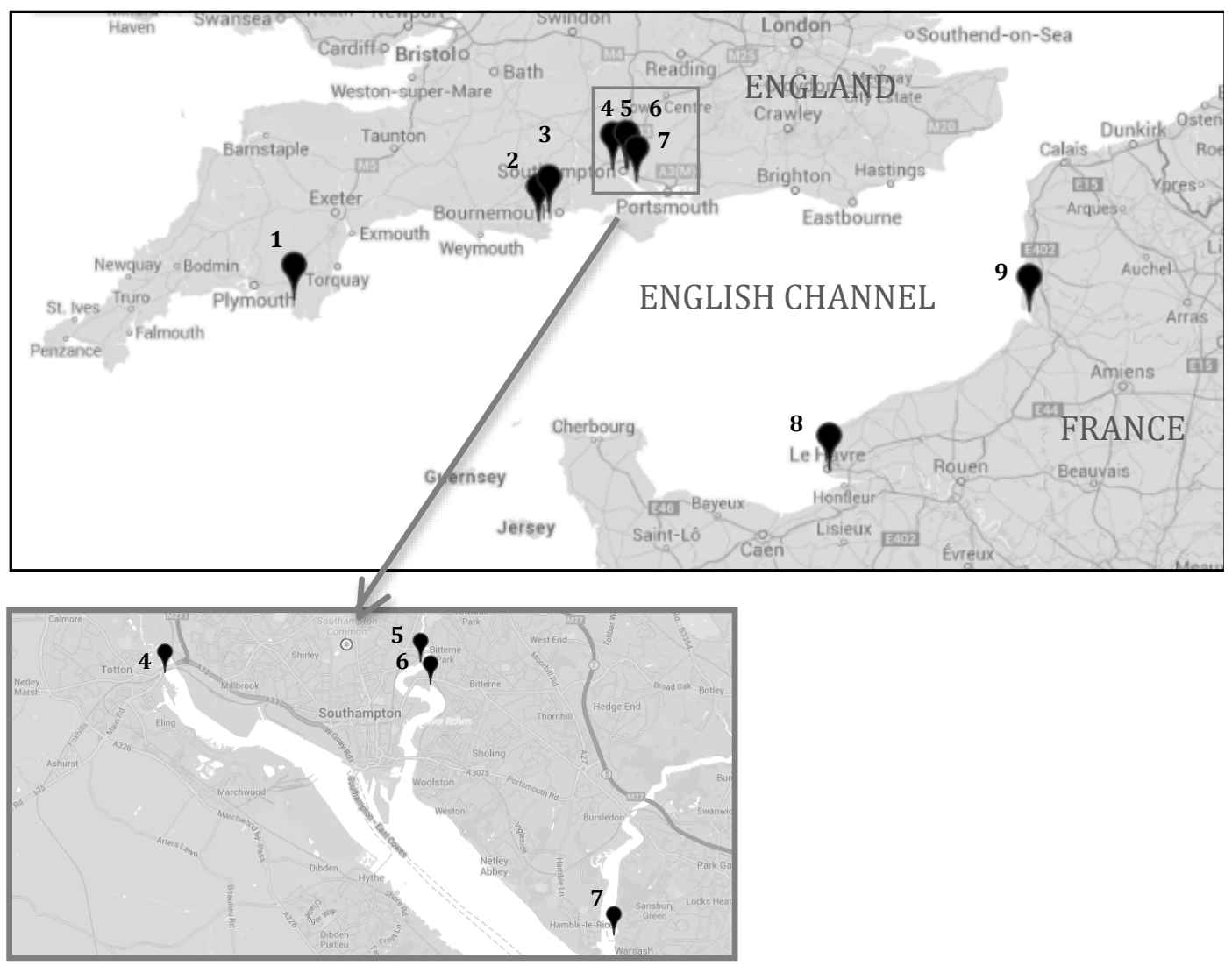


$5 \quad$ Figure 2

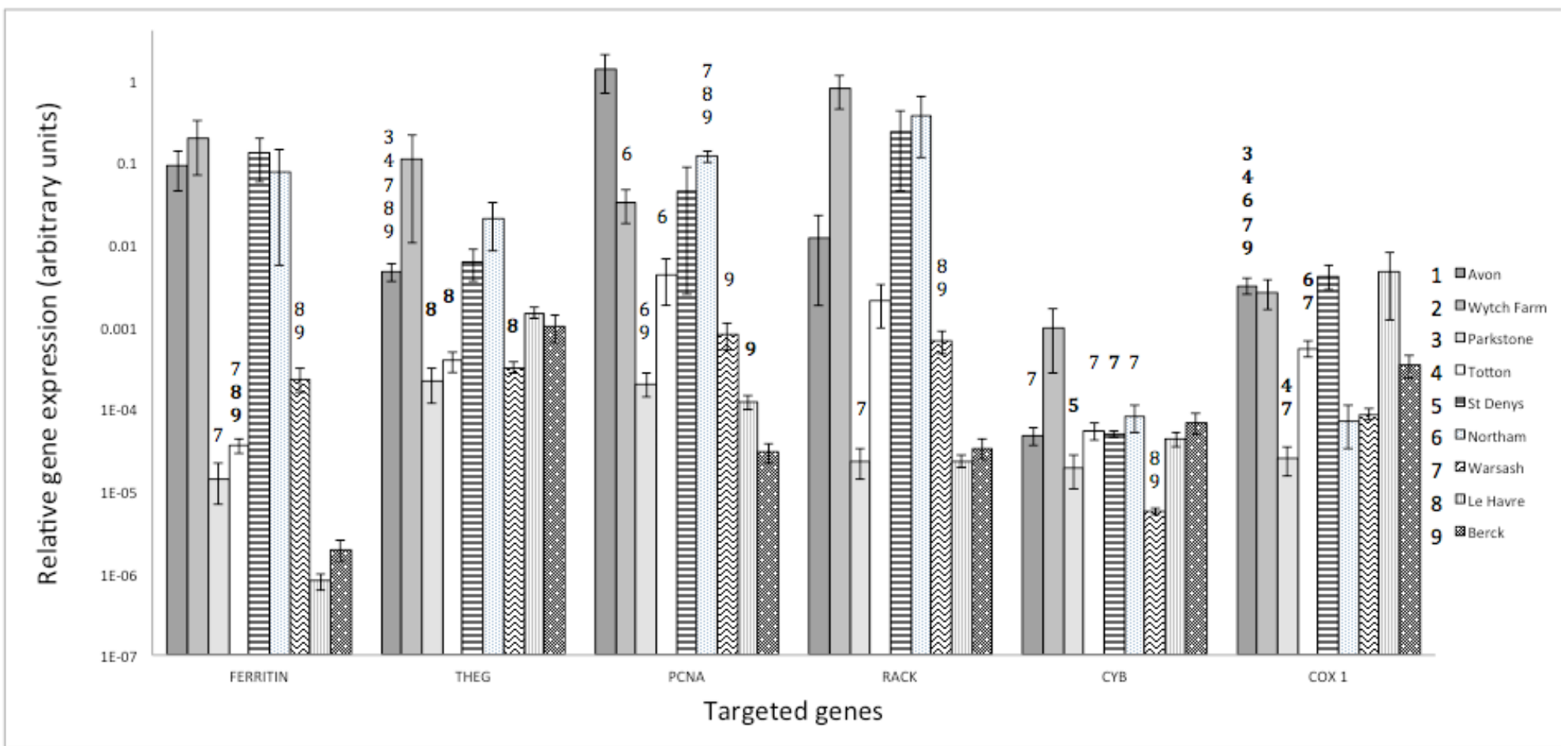


Figure 3.

31

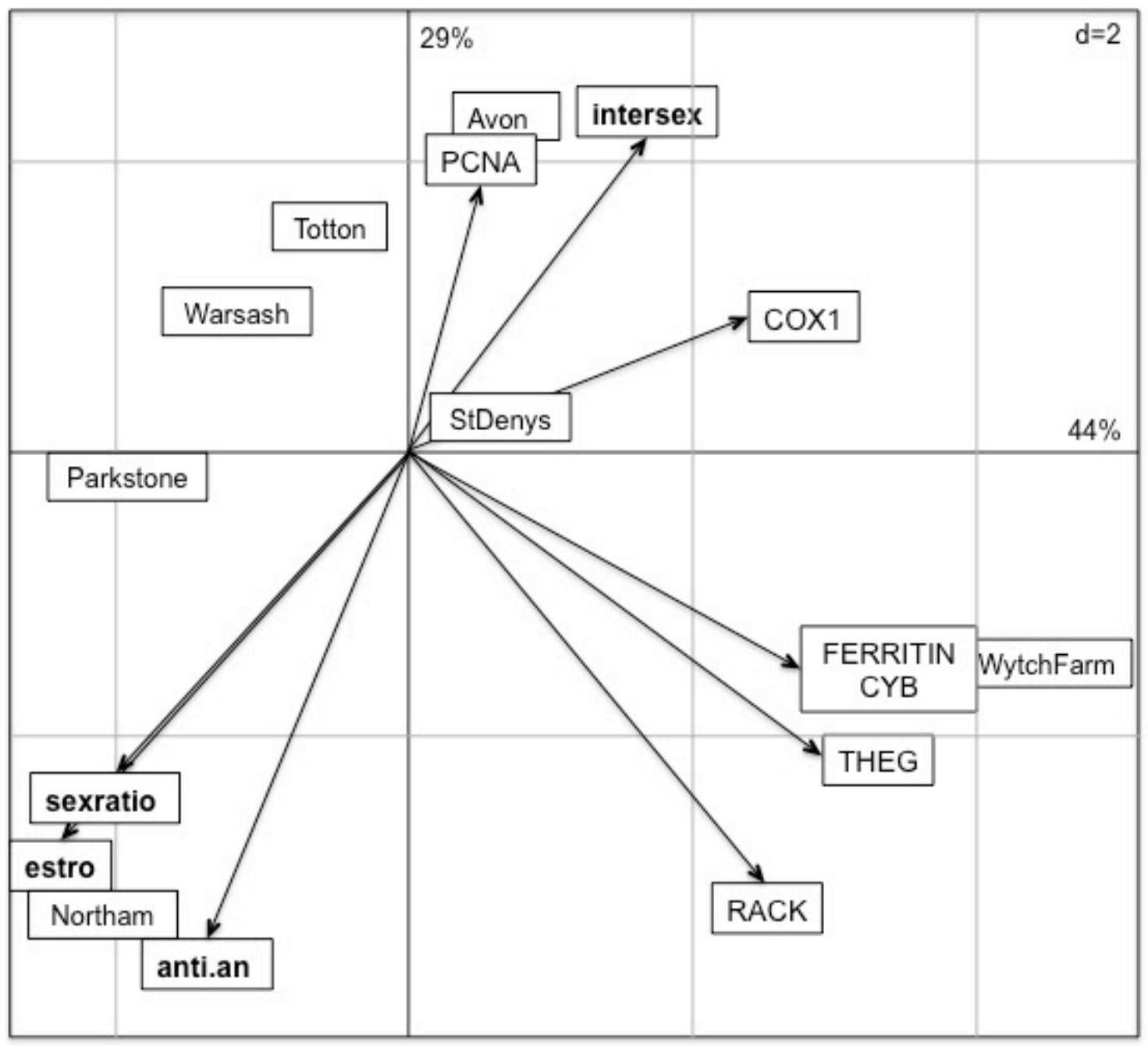

